\title{
MARKET REACTION TO TAX AMNESTY INFORMATION: SURVEY ON INDONESIAN \\ PUBLIC LISTED COMPANIES
}

\section{MARKET REACTION TO TAX AMNESTY INFORMATION: SURVEY ON INDONESIAN PUBLIC LISTED COMPANIES}

\author{
Arie Pratama* \\ Departmenet of Accounting, Faculty of Economics and Business, Universitas Padjadjaran, \\ Indonesia
}

\begin{abstract}
This article described the Indonesian market reaction on the announcement of tax amnesty related information in the financial statements. Statement of Financial Accounting Standards (SFAS) No. 70 required companies to recognized and measured the tax amnesty's assets. Tax amnesty's asset was selected as information to be analyzed. The total of 141 observations from the year $2016-2017$ financial statements were selected as a sample. To measure market reaction, three proxies were used: value relevance, cumulative abnormal return, and trading volume activity. Data analyzed using linear regressions. This article showed that the market reacted to tax amnesty information, although the level of reaction was low. This article also showed that in general, market reaction toward tax amnesty was positive. These results also implied that the SFAS 70's accounting requirement improved the quality of financial statements.
\end{abstract}

Keywords: tax amnesty, SFAS 70, tax amnesty's asset, market reaction.

\section{INTRODUCTION}

This article provides insight into Indonesian tax amnesty programme (TA) that occurred for 9 months, from July 2016 - March 2017. TA resulted in more than Rp. 115 trillion state's income and the total of declaration and repatriation were Rp. 4.737 and Rp. 147 trillion, respectively. TA was believed to create long-term tax compliance, and therefore will assist the government in maintaining it's a source of revenue (Andreoni, 1991; Alm and Beck, 1993; Luitel and Sobel, 2007). TA was also believed to increase investor's trust toward the company, and like the results, the company's would likely receive more funds and capital, if it's participating in a TA (Torgler, 2002; Mehmet, 2015).

Indonesian TA was believed to be a successful one, supported by an improvement in a tax administration system (Waluyo, 2017). Indonesia Stock Exchange's reported that tax amnesty program had positive impacts on the stock market, as reflected by an increase in the 2016 stock exchange's capitalization by 18.35 percent from its position in late 2015 . The average transaction value on a daily basis also increased to at least Rp 7 trillion (US\$538.4 million). In addition, the trade frequency hit a new record on July 13, 2016, at 377,000 times. The success level of the program can also be contributed by the regulations, in which the regulations asked the taxpayer to disclose the tax amnesty information clearly and precisely (Pommerehne and Zweifel, 1991; Torgler and Schalteggler, 2005).

Although the market reacted positively toward tax amnesty, there is a critic toward the financial information about tax amnesty. The information about tax amnesty presented in the financial statements. Indonesia has SFAS 70 that required the company to present tax amnesty's assets and liabilities. SFAS 70's requirement would result in the increase of tax amnesty's assets and liabilities, but the assets will be higher compared to liabilities (Winarso and Panday, 2018). Higher assets will improve several financial ratios, mostly liquidity, and solvability. However, SFAS 70 were analyzed heavily in the previous research, and the accounting requirements in SFAS 70 were deemed too *Corresponding Author email address: arie.pratama@,fe.unpad.ac.id 


\section{AFEBI Accounting Review (AAR) \\ Volume 6, No 01 (2021)}

"relaxing", and have a potential to impair the quality of information (Rinaldi, 2017; Natania and Davianti, 2018). SFAS 70 required company to present TA's asset according to the fair value, as described in the Notification Letter of Tax Amnesty. The value described determined freely by taxpayer, so it might be not in accordance with the criteria of fair value in accounting. This could lead to a misinterpretation of the company's financial condition (Farida, 2018). Previous articles concerning tax amnesty and market reaction showed the contradictive results. Tax amnesty's information in the financial statements shows no reaction of tax amnesty information (Wibowo and Darmanto, 2017; Agustin, et.al, 2018; Wiratama and Rikumahu, 2018). All previous researches only used event study, and difference test for their hypothesis testing. The variables that were tested were only market reaction related proxies: value relevance, abnormal return, and trading volume activity. There are no variables concerning the tax amnesty that being analyzed in those researches.

This research tried to test whether tax amnesty's information has relation with market reaction. This research tried to improve the model by adding the variables concerning tax amnesty's information. There are 3 pieces of information: tax amnesty's assets, tax amnesty's liabilities, and redemption fee. Not all companies disclosed tax amnesty's liabilities and redemption fee, so for generalizability reason, tax amnesty's assets are used as variables. Asset information tells the resources that were made available for company to utilize, so the higher the asset, the higher will be the performance expectation. This research will also try to look market reaction simultaneously, by analyzing 3 related variables: value relevance, abnormal return, and trading volume activity. By analyzing 3 proxies related to market reaction, we hope that the robust market reaction can be described.

The contribution of this research was to provide valuable information about the accounting requirement set by the Indonesian accounting standards board, concerning the effect of the accounting requirements to the users of information. The accounting requirement needs to be robust, so the information will reach the optimum level of describing the company's condition. Tax information in financial statements not only provide information concerning compliance to tax laws but can also describe any future payment or benefit that can be received as the taxpayer. (Harding, 2017) The nonrobustness of accounting treatment for tax amnesty might raise the question whether the SFAS 70's can improve the quality of accounting information. The rest of the paper was divided as follows: Section 2 would describe brief literature review to develop the research hypotheses, section 3 would describe the research method, section 4 would describe research results, implications and discussions of the results, and the last section, section 5 would conclude the article.

\section{LITERATURE STUDY}

The company provides information about tax in many various reporting. The focus of tax reporting is to show the level of tax compliance (Harding, 2017). Gupta (2014) stated that accounting standards tend to report tax conservatively, so the focus was to report tax expense and liabilities, since both items were also shown compliance, therefore the report on tax compliance can be perceived as a positive report. On the other side, tax information in the assets account is usually prepaid taxes and deferred tax assets. The negative report caused by the nature of the tax as an uncertain amount, that can be reassessed or audited by the government. (Seetharaman, et.al, 2011). Therefore, previous literature showed that tax information in the assets section was usually not relevant for a financial analyst, due to the uncertainties of their economic benefit. (Kubick, et.al, 2014; Tumpach and Stankova, 2014). 


\section{MARKET REACTION TO TAX AMNESTY INFORMATION: SURVEY ON INDONESIAN PUBLIC LISTED COMPANIES}

Efficient market hypothesis had shown that the stock market reacts based on the information. Most of the emerging markets, including Indonesia had been classified as semi-strong or weak form of the market (Malkiel, 2005; Andrianto and Mirza, 2016). This forms shown that market reacts based on several pieces of information, which might be relevant or irrelevant for investors decision making. Financial information presented in financial statements has constraints, including cost-benefit, and materiality, Several transactions cannot be presented in financial statements since it was not fulfil accounting recognition criteria (Scott, 2006; IFRS, 2010). Tax amnesty rarely occurred, and the government can set different tax amnesty policies and procedures (Alm and Rath, 1998; Buckwalter, et.al, 2013). Therefore, there is no international accounting standard that regulates the accounting treatment for tax amnesty.

Indonesia creates its own accounting standard, SFAS 70. This standard provide "relaxing" treatments, such as: (1) Company were able to record the assets prospectively and no need to restate previous years financial statements (2) Company able to record the asset value as in accordance with tax rules only, readjustment to the asset's fair value is an option, and (3) few disclosures requirements. SFAS 70 required company to disclosed 4 things: (1) Date of certificate of tax amnesty; (2) Serial number of the certificate of tax amnesty; (3) Total value of tax amnesty assets, and; (4) Total value of tax amnesty liabilities. SFAS 70's "relaxing" requirement provides easier accounting procedure, but in the other hand, SFAS 70 might hide the important information about company's tax management, therefore will reduce the positive perception of the investor (Natania and Davianti, 2018). Based on the assessment conducted in the financial statements, most companies disclosed only tax amnesty's assets. Assets are shown the future economic benefit that can derived value added to the company. However, in the tax amnesty's assets recognition, the assets recognized based on the certificate of tax amnesty, in which the asset's value was determined solely by a taxpayer. Taxpayer didn't require to measure the asset's value at the fair value, so the asset value might be questionable (Pratama, 2019). SFAS 70 provide a voluntary opportunity for the taxpayer to re-measure it's tax amnesty assets at fair value, but there is no obligation to disclose it. If we looked at another perspective, tax amnesty's assets resulted from the income that never been reported previously, so in the perspectives of the accounting framework, the recognition should be treated as error correction. Correction of error must be treated retrospectively, which could cause negative implications of a company's reputation (Goodwin, et.al, 2008). Thus, there was a high probability of taxpayer wouldn't participate in tax amnesty, if the accounting treatment were not changed. Another problem would be audit issues, where the retrospective adjustment required restatement of the financial statement, in which the auditor might review the prior opinion of financial statements, and might decide to revoke the opinion (Frost, 1997).

The uncertainty resulted from unique accounting treatment of tax amnesty's asset might have effect to the investor that analyzed the information. The tax was always became sensitive information to the investor since tax information reflects the company's level of compliance to a government rule (Pratama, 2018a). The company that participates in tax amnesties can be said pleaded guilty of conducting past tax avoidance or evasion, so the disclosure of the assets was a confession of bad business practices. However, the recognition of tax amnesty's assets might improve financial conditions and ratios, especially in liquidity and solvability. Overall reaction to tax amnesty was positive, but it generally caused by the level of tax revenue generated from the program (Marchese and Privileggi, 1997). In the micro level, the information disclosed by the company might behave differently with the macro one. Tax information rarely used or become decision factors for investors, 


\section{AFEBI Accounting Review (AAR) \\ Volume 6, No 01 (2021)}

except if there is any change in policy, such as new tax policy or change in tariff (Horton and Serafeim, 2010). The company that had a tax problem and disclosed it in the financial statements might also incite investor reaction (Hanlon and Slemrod, 2009). Based on the literature review, it can be said that tax information might incite a reaction from the markets, although it can be a positive or negative, so the author proposes the research hypothesis as follow:

\section{H: Tax amnesty's assets information had an influence on the market reaction}

\section{RESEARCH METHODS}

The method used in this research was an explanarory quantitative method. Variables in this research were tax amnesty's assets as an independent variable and market reaction as the dependent variable. Tax amnesty's assets information taken from the statement of financial position and measured using natural logarithm om tax amnesty's asset value. Market reaction used 3 proxies: (1) value relevance; (2) cumulative abnormal return; (3) trading volume activity. Value relevance was usually proxied by stock price. Stock price serves as equity market performance, and if the accounting information were relevant and reliable, the consequence of this information is fully reflected in the stock price (Barth, et.al, 2001). Abnormal return defined as the difference between daily stock actual return and daily stock expected return, measured by market return. The difference between actual and expected return signified the investor change due to certain information (Barber and Lyon, 1997). Trading volume activity measured investor's decision whether to buy or sell stock. Investors activity were triggered by information, including information included in the financial statement (Bamber, et.al., 2011)

The population is the company that listed in Indonesian Stock Exchange that participated in tax amnesty during 2016 - 2017. It is not possible to obtain the actual data of tax amnesty participants, due to the secrecy maintained by Directorate General of Tax, so the participation is indicated by the information of the adoption of SFAS 70 in company's financial statement. The total population is 552 data. From 552 data, 88 data were eliminated due to currency differences (used USD, while the common currency is IDR), 233 data were again eliminated, since they did not include any tax amnesty's asset in their statement of financial position, due to materiality concern, or the company voluntarily choose to remeasure the tax amnesty's assets to the accounting fair value. After the remeasurement done, the company classified the assets to the normal account, so it was difficult to predict how much the tax amnesty's assets in that situation, 82 company were eliminated due to incomplete data, so the final data is 151 . The data will be analyzed using simple linear regression. Since there were three dependent variables, then there will be 3 linear regression model to be tested.

Variable measurement can be seen on Table 1 below:

Table 1

Variable Measurement

\begin{tabular}{|l|l|l|}
\hline \multicolumn{1}{|c|}{ Variables } & Symbol & \multicolumn{1}{c|}{ Measurement } \\
\hline \multicolumn{2}{|c|}{ Dependent Variables } \\
\hline$\left(Y_{l}\right)$ & VR & $\begin{array}{l}\text { The geometric mean of stock's closing price from } \\
\text { day 1 until day 5, since the date of financial } \\
\text { Salue Relevance }\end{array}$ \\
\hline
\end{tabular}




\begin{tabular}{|c|c|c|}
\hline $\begin{array}{l}\left(Y_{2}\right) \\
\text { Cumulative } \\
\text { abnormal return }\end{array}$ & CAR & $\begin{array}{l}\text { The geometric mean of stock's cumulative } \\
\text { abnormal return from day } 1 \text { until day } 5 \text {, since the } \\
\text { date of financial statement publication. } \\
\text { Abnormal return = Actual return }- \text { Expected } \\
\text { return } \\
\text { Actual return }=(\text { Stock closing price at } \mathrm{t}-\mathrm{Stock} \\
\text { closing price at } \mathrm{t}-1) / \text { Stock closing price at } \mathrm{t}-1 \\
\text { Expected return }=(\text { IDX closing index at } \mathrm{t}-\text { IDX } \\
\text { closing at } \mathrm{t}-1) / \mathrm{IDX} \text { closing index at } \mathrm{t}-1 \text { at } \mathrm{t}-1\end{array}$ \\
\hline $\begin{array}{l}\left(Y_{3}\right) \\
\text { Trading Volume } \\
\text { Activity }\end{array}$ & TVA & $\begin{array}{l}\text { The geometric mean of trading volume activity } \\
\text { from day } 1 \text { until day } 5 \text {, since the date of financial } \\
\text { statement publication }\end{array}$ \\
\hline \multicolumn{3}{|c|}{ Independent Variables } \\
\hline $\begin{array}{l}(X) \\
\text { Tax Amnesty’s } \\
\text { Asset }\end{array}$ & ASSET & Natural logarithm of tax amnesty's asset value \\
\hline
\end{tabular}

This research used the simple linear regression to check the influence between dependent and independent variables. Since there were 3 different dependent variables, we used simple linear regression, 3 times.

\section{RESULTS AND DISCUSSION}

The descriptives of each variable can be shown in Table 2 below:

Table 2

Variable Descriptives

\begin{tabular}{|c|c|c|c|c|}
\hline Variables & Minimum & Maximum & Mean & $\begin{array}{c}\text { Std. } \\
\text { Deviation }\end{array}$ \\
\hline ASET & 9.21 & 31.58 & 21.2916 & 2.52293 \\
\hline VR & 3.91 & 10.16 & 6.1964 & 1.37275 \\
\hline CAR & -.0104 & .0111 & .000054 & .0044315 \\
\hline TVA & 4.61 & 20.10 & 12.0828 & 3.57966 \\
\hline
\end{tabular}

Averagely, companies disclosed TA asset amounted Rp. 1,691,055,790.53 (2,7128 21.2916$)$. The spread of TA asset was high, as shown in the large differences between maximum amount (Rp. 48,678,074,428,694.70) and minimum amount (Rp. 9,812.46). The high spread might be caused by several factors: (1) Some firms might try to reduce the redemption fee paid to tax office by decreasing the TA Asset; (2) Some firms might select some of the TA asset to be revalued in accordance with the accounting fair value, resulting in the reduction of TA asset, since the SFAS 70 required the 


\section{AFEBI Accounting Review (AAR) \\ Volume 6, No 01 (2021)}

company that revalued the TA asset to combine the value to its respective asset account. The mean for VR is Rp. 471,98 (2,7128 $\left.{ }^{6.1964}\right)$. The mean for CAR is .000054, the positive sign mark that most of the stock in IDX perform better than expectation, and the mean for TVA is 12.0828 or 172 million shares outstanding.

The regressions result can be shown at below:

Table 3

Regression Result

\begin{tabular}{|l|c|c|c|c|c|c|}
\hline \multirow{2}{*}{ Var } & \multicolumn{2}{|c|}{ VR } & \multicolumn{2}{c|}{ CAR } & \multicolumn{2}{c|}{ TVA } \\
\cline { 2 - 7 } & B & Sig & B & sig & B & Sig \\
\hline C & 3.39412 & $0.0005^{* *}$ & -0.00697 & $0.0269^{*}$ & 6.44148 & $0.0115^{*}$ \\
\hline ASSET & 0.13161 & $0.0036^{* *}$ & 0.00033 & $0.0247 *$ & 0.26496 & $0.0255^{*}$ \\
\hline $\mathrm{R}^{2}$ & \multicolumn{2}{|c|}{$5,18 \%$} & \multicolumn{2}{c|}{$2,84 \%$} & \multicolumn{2}{c|}{$2,80 \%$} \\
\hline
\end{tabular}

Notes:

** : significant at $\alpha=1 \%$

* $\quad$ : significant at $\alpha=5 \%$

The table showed us that TA asset information did result in a positive market reaction. This result also showed robustness, since it showed the same and consistency results. The $\mathrm{R}^{2}$, however, is small, the highest is only $5 \%$. Therefore we can conclude that tax amnesty information had influenced the market reaction.

The result above can show how the markets reacted to tax-related information in the financial statements. First, the low level of $\mathrm{R}^{2}$ coefficient confirmed that the tax-information generally has low level of attraction for the investors. Although tax amnesty event can be considered as an unusual and infrequent, but not all of the investor have a high level of understanding concerning tax amnesty's information in the financial statements. Tax information currently not have adequate disclosures requirement in the financial statements (McGill and Outslay, 2004). Accounting standards board could not add more disclosures requirement since, in many jurisdictions, information concerning tax is very secretive information (Hanlon, 2003). Indonesian tax amnesty information declared to be secret information, as stipulated in the Tax Amnesty Laws. So the more requirement of accounting disclosures might be conflicted with the secret nature of tax amnesty's information. Another reason for the low understandings, might came from the nature of the tax amnesty. Since tax amnesty is an extraordinary event, it usually being excluded from the basis for the company's performance analysis. Hoyle et.al (2017) stated that extraordinary items have many weaknesses, including: (1) inconsistent criteria for defining extraordinary items; (2) variation in financial statement placement, and (3) the changing nature and size over the years. The "unfairness" nature that exists in measuring tax amnesty's assets can also be another reason of why the financial analyst, or the investors, not considered the information of tax amnesty in the financial statements.

Second, the overall market reaction to tax amnesty's information is positive, as indicated in the Beta sign. This result showed us that investors perceived tax amnesty to be a good event. The increase of the assets will improve several ratios, especially liquidity and solvability, therefore, reduce risks in companies (Scott, 2006). Tax information also showed compliance with the law, and by 


\section{MARKET REACTION TO TAX AMNESTY INFORMATION: SURVEY ON INDONESIAN PUBLIC LISTED COMPANIES}

disclosing the information in the financial statements, it can also be implied that company that follows tax amnesty had greater compliance. The greater compliance can also lower the risk of getting any inspections or sanctions, therefore will reduce any uncertainty causing with tax.

This tax amnesty's accounting can also be a new point of view of political accounting. Deegan (2016) stated that the accounting standards might not free from interventions from specific group interest, however, the pure positive or normative approach to construct standards might result in the overload of the standards, so the intervention can be viewed as a solution to avoid this problem. SFAS 70 as an accounting standard might not be a perfect standard in comparison with the conceptual framework. But the relaxing requirement of SFAS 70, can be seen as a political compromise between three parties: Investor, whose demand information concerning the company's participation in tax amnesty; Company, which want an accounting requirement that provide relevant, but in the efficient way, and Regulators, which want to maintain order and provide a robust gateway of the information.

\section{CONCLUSION}

In the end, the tax amnesty program has concluded. From the view of accounting information, tax amnesty did provide information about the increase in the company's economic benefit, and investor reacts positively to that information. We can see that SFAS 70, as accounting standards, is not without weakness, but the SFAS 70 indeed provide information about company's action concerning tax amnesty, and the requirement can be said to be adequate.

The "political" nature of this accounting standard might set a precedent for a future event, like the future tax amnesty's event, or any kind of governmental event. But, as we can see in the results, investors in Indonesia seemed to be positive as long as the information is positive. The Indonesian investor is still yet to shift their attention to the quality of requirements, they were still focused on the results of the requirements.

This research hopes to trigger another kind of research in the future. The common problem is not all the data concerning tax were available for research. If in the future, the data were available, the future researcher could do more exploration, concerning the types of assets that were disclosed in tax amnesty. Current and non-current assets have a different economic life span and have a different impact on companies operation, so the composition difference could trigger different reaction to the markets. The source of the asset acquiring can also different, and might trigger a different reaction. Therefore, the researcher hopes that in the future, more data concerning tax amnesty might be available for the public, so the more robust research may be produced at that time.

\section{REFERENCES}

Agustina, L.Gunawan, Y. Chandra, W. (2018) 'The Impact of Tax Amnesty Announcement towards Share Performance and Market Reaction in Indonesia', Accounting and Finance Research, Vol. 7 No. 2, pp. $39-47$.

Ali, A., \& Hwang, L. (2000). 'Country-Specific Factors Related to Financial Reporting and the Value Relevance of Accounting Data'. Journal of Accounting Research, 38(1), 1-21.

Andreoni, J. (1991). 'The desirability of a permanent tax amnesty', Journal of Public Economics, Vol. 45 No. 1, pp. 143-159.

Andrianto, Y., Mirza, A.R., (2016) 'A Testing of Efficient Markets Hypothesis in Indonesia Stock Market', Procedia - Social and Behavioral Sciences, Vol. 219, pp. 99-103. 
Alm, J. and Beck, W. (1993). 'Tax Amnesties and Compliance in the Long Run: A Time Series Analysis', National Tax Journal Vol. 47 No. 1, pp. 53-60.

Bamber, L., Barron, O., and Stevens, D. (2011) 'Trading volume around earnings announcements and other financial reports: Theory, research design, empirical evidence, and directions for future research.', Contemporary Accounting Research 28, pp. 437-471.

Barber, B., M., Lyon, J., D., (1997) 'Detecting long-run abnormal stock returns: The empirical power and specification of test statistics', Journal of Financial Economics, Volume 43, Issue 3, pp 341-372,

Barth, M.E., Beaver, W.H., Landsman, W.R., (2001), 'The relevance of the value relevance literature for financial accounting standard setting: another view', Journal of Accounting and Economics, Volume 31, Issues 1-3, Pages 77-104,

Buckwalter, N.D. Sharp, N.Y. Wilde, J.H., and Wood, D.A. (2013) 'Are state tax amnesty programs associated with financial reporting irregularities?’, Public Finance Review, Vol. 00 No. 0, pp. $1-26$.

Deegan, C. (2016). Financial Accounting. 8th ed. North Ryde, NSW Sydney Australia: McGraw Hill. Farida, A. (2018), 'Dilema Opsi dalam PSAK 70 tentang Akuntansi Tax Amnesty (Dillema of SFAS 70 concerning Accounting for Tax Amnesty)', Moneter: Jurnal Akuntansi, Manajemen, dan Perbankan, Vol. 5, Iss. 1, pp. 53 - 56.

Frost, C.A. (1997) 'Disclosure policy choices of UK firms receiving modified audit reports', Journal of Accounting and Economics, 23, pp. 163-187.

Gupta, S., Mills, L.F., and Towery, E.M. (2014). 'The Effect of Mandatory Financial Statement Disclosures of Tax Uncertainty on Tax Reporting and Collections: The Case of FIN 48 and Multistate Tax Avoidance'. The Journal of the American Taxation Association, Fall 2014, Vol. 36, No. 2, pp. 203-229

Hair, J.J., Black, W.C., Babin, B.J. and Anderson, R.E. (2009) Multivariate Data Analysis, $7^{\text {th }}$ ed., Pearson Higher Education, New York.

Harding, Michelle Kim, (2017) 'The Impact of Increased Tax Return Reporting on Financial Statement Tax Disclosure Quality: Evidencefrom IRS Schedule U TP.’ Ph.D. diss., University of Tennessee.

Hanlon, M., (2003) 'What can we infer about a firm's taxable income from its financial statements?'NationalTax Journal 56, 831-863.

Hanlon, M., and Slemrod, J., (2009) 'What does tax aggressiveness signal? Evidence from stock price reactions to news about tax shelter involvement', Journal of Public Economics, 93, issue 1-2, p. $126-141$

Horton, J. \& Serafeim, G (2010) 'Market reaction to and valuation of IFRS reconciliation adjustments: first evidence from the UK', G. Rev Account Stud, 15: 725.

Hoyle, J.B. Paik, G.H. (Daniel) and Shi, R. (Cathy) (2017) 'Extraordinary Items-An Elusive Concept'. Accounting Historians Journal, Vol. 44, No. 2, pp. 139-156.

Kubick, T. R., Lynch, D. P., Mayberry, M. A., \& Omer, T. C. (2014)'The Effects of Increased Financial Statement Disclosure Quality On Tax Avoidance: An Examination of SEC Comment Letters'.

Luitel, H.S. and Sobel, R.S. (2007). 'The revenue impact of repeated tax amnesties', Public Budgeting \& Finance, Vol. 27 No. 1, pp. 19-38. 


\section{MARKET REACTION TO TAX AMNESTY INFORMATION: SURVEY ON INDONESIAN \\ PUBLIC LISTED COMPANIES}

Malkiel, B. G. (2005), 'Reflections on the Efficient Market Hypothesis: 30 Years Later, Financial Review, 40, pp. 1-9.

Marchese, C. \& Privileggi, F. (1997) 'Taxpayers' attitudes toward risk and amnesty participation: economic analysis and evidence for the Italian case,' Public Finance, Vol. 52 No. 3/4, pp. 394-410.

McGill, G., \& Outslay, E. (2004). 'Lost in Translation: Detecting Tax Shelter Activity in Financial Statements',National Tax Journal, 57(3) pp. 739-756.

Mehmet N. (2015). 'The Effects Of Behavioral Economics On Tax Amnesty',International Journal of Economics And Financial Issues. Vol 5, Iss. 2: pp. 580-589.

Natania, E.S, and Davianti, A. (2018) 'An Accounting Perspective of Tax Amnesty in Indonesia', Journal of Accounting Auditing and Business, Vol. 1 No. 1, pp. 1-18.

Pommerehne, W.W. \& Zweifel, (1991) 'Success of a tax amnesty: At the polls, for the fisc?' P. Public Choice, Vol. 72, Iss. 2 - 3, pp. 131 - 165.

Pratama, A. (2018a). 'Determinants of Indonesian Public Listed Companies to Participate in the Tax Amnesty'. Indonesian Journal of Sustainability Accounting and Management, 2(2), 136-152.

Pratama, A. (2019). 'Analysis of Tax Amnesty Disclosures, Tax Avoidance, and Firm Value'. Indonesian Journal of Contemporary Accounting Research, 1(1), 136-152.

Rinaldi, Rinaldi (2017) 'Dampak Tax Amnesty Terhadap Laporan Keuangan Dan Pengaruhnya Kepada Nilai Perusahaan (Impact of Tax Amnesty Toward Financial Statements and Firm Value)'. ADHUM (Jurnal Penelitian dan Pengembangan Ilmu Administrasi dan Humaniora), Vol. 7, Iss.1. pp. 33-43.

Seetharaman, A., Sun, Y., \& Wang, W. (2011). 'Tax-Related Financial Statement Restatements and Auditor-Provided Tax Services'. Journal of Accounting, Auditing \& Finance, 26(4), pp. 677698.

Scott, W. R. (2006). Financial Accounting Theory $6^{\text {th }}$ edition. Prentice Hall, New York.

Torgler, B. (2002), 'Speaking to Theorists and Searching for Facts: Tax Morale and Tax Compliance in Experiments'. Journal of Economic Surveys, Vol. 16: pp. 657-683.

Torgler, B. and Schaltegger, C.A. (2005). 'Tax amnesty and political participation', Public Finance Review, Vol. 33 No. 1, pp. 403-431

Tumpach, Miloš, and Stanková, Adriana (2014) 'Current Income Tax Disclosures in Separate Financial Statements of IFRS Adopters in Slovakia', European Financial and Accounting Journal, University of Economics, Faculty of Finance and Accounting, Prague, Vol. 9, Iss. 4, pp. $76-85$

Waluyo (2017) 'Tax Amnesty and Tax Administration System: An Empirical Study in Indonesia', European Research Studies Journal, Vol. XX, issue 4B, pp. 548-556.

Wibowo, A. and Darmanto, B. (2017) 'Reaction of Indonesian Capital Market Investors to the Implementation of Tax Amnesty', Journal of Finance and Banking, Vol. 21 No. 4, pp. 597 608.

Wiratama, Y.M.W, and Rikumahu, B. (2018) 'Analysis of Abnormal Return Difference before and After Tax Amnesty Announcement toward Indonesia Stock Exchange (IDX) (Case Study on KOMPAS-100), International Journal of Scientific and Research Publications, Volume 8, Issue 2, pp. $452-457$. 
AFEBI Accounting Review (AAR)

Volume 6, No 01 (2021)

Winarso, W and Panday, R (2018) 'Impact Implementation Of Psak 70 Related To Tax Amnesty On Reporting Of The Firm (Case Study On CV Btari Senja)', Jurnal Manajemen Bisnis, Vol. 9, Iss. 1 , pp. $25-35$. 